\title{
Growth hormone therapy in children with partial growth hormone deficiency. Are we treating the right patients?
}

Terapia rekombinowanym hormonem wzrostu dzieci z częściowym jego niedoborem.

Czy kwalifikujemy do leczenia właściwych pacjentów?

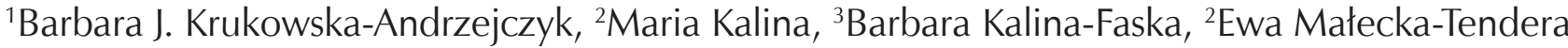
1'Division of Pediatrics and Neurology of Developmental Age, The Independent Public Clinical Hospital No. 6 of the Medical University of Silesia in Katowice, John Paul II Upper Silesian Child Health Centre, Poland ${ }^{2}$ Department of Paediatrics and Paediatric Endocrinology, School of Medicine in Katowice, Medical University of Silesia, Poland
${ }^{3}$ Department of Paediatrics and Paediatric Endocrinology, School of Medicine in Katowice, Medical University of Silesia, Poland

\begin{abstract}
Introduction: Diagnosis of growth hormone deficiency (GHD) in children with short stature, whose height is below -2SD for the population norm, is based on the assessment of growth hormone $(\mathrm{GH})$ peaks in stimulation tests. However, cut-off values for $\mathrm{GH}$ secretion are arbitrary and vary in different centres. Indications for recombinant $\mathrm{GH}$ therapy remain disputable in children with $\mathrm{GH}$ concentrations between 5 and $10 \mathrm{ng} / \mathrm{ml}$ (pGHD).

Aim of the study: The aim of our study was to assess the effects of rhGH therapy in children with transient pGHD deficiency compared to untreated children with idiopathic short stature (ISS).

Material and methods: The study group comprised 54 patients at the mean age of 13.5 (SD 2.36) years, who were diagnosed as pGHD and treated with rhGH. The control group comprised 32 subjects with ISS matched for sex and age, untreated with rhGH.

Results: Mean final height was within the normal range for population norms in both groups. The average height gain was statistically significant at $-1.3 \mathrm{SD}(p<0.001)$ for the study group and $-1.02 \mathrm{SD}(p \leq 0.001)$ for the control group. However after exclusion of children with familial short stature (FSS) the height gains were, respectively, 1.41 SD \pm 0.67 for the study group and 1.22 SD \pm 0.77 for the control group, without statistical significance.

Conclusions: The results of our study did not show beneficial effects of rhGH treatment in children with pGHD as compared to untreated ISS subjects. Therefore, it is necessary to determine criteria other than arbitrarily established GH concentration for starting rhGH treatment in children with pGHD.
\end{abstract}

Key words:

short stature, partial growth hormone deficiency, growth hormone treatment.

\section{Streszczenie}

Wprowadzenie: Rozpoznanie niedoboru hormonu wzrostu $(\mathrm{GH})$ u dzieci niskorosłych, których wzrost mieści się poniżej 2 SD dla normy populacyjnej, oparte jest na wartości stężenia GH w testach stymulacyjnych. Wartość krytyczna GH w testach jest arbitralnie przyjęta i różni się między ośrodkami badawczymi. Wskazania do leczenia rekombinowanym hormonem wzrostu (rGH) u dzieci ze stężeniem GH w teście pomiędzy 5 a $10 \mathrm{ng} / \mathrm{ml}$ (pGHD) są nadal dyskusyjne.

Cel pracy: Porównanie efektów leczenia rGH dzieci z pGHD w odniesieniu do grupy kontrolnej złożonej z dzieci z idiopatyczną niskorosłością (ISS), nieleczonych rGH.

Materiał i metody: Grupę badaną stanowiło 54 dzieci w średnim wieku 13,5 roku (SD 2,36) ze zdiagnozowanym częściowym niedoborem hormonu wzrostu leczonych rGH. Grupę kontrolną stanowiło 32 dzieci z ISS nieleczonych rGH dobranych pod względem płci i wieku. Wyniki: Średni wzrost ostateczny dzieci z obu grup mieścił się w granicach normy populacyjnej. Średni przyrost wzrostu różnił się istotnie pomiędzy grupami: 1,3 SD $(p<0,001)$ dla grupy badanej w porównaniu z 1,02 SD ( $p<0,001)$ dla grupy kontrolnej. Różnica ta była istotna statystycznie $(p<0,05)$. Po wyłączeniu grupy dzieci z rodzinnym niskim wzrostem (FSS) przyrost wzrostu był odpowiednio na poziomie 1,41 SD $\pm 0,67$ dla grupy badanej i 1,22 SD $\pm 0,77$ dla grupy kontrolnej. Różnica ta nie była istotna statystycznie. 
Wnioski: Wyniki badania nie wskazują na korzystny efekt leczenia rGH dzieci z pGH w porównaniu z dziećmi z ISS. Wskazane jest więc ustalenie innych kryteriów niż wyrzut GH w testach stymulacyjnych kwalifikowania do terapii hormonalnej dzieci z częściowym niedoborem $\mathrm{GH}$.

Słowa kluczowe:

leczenie hormonem wzrostu, niski wzrost, częściowy niedobór hormonu wzrostu.

\section{Introduction}

Routine diagnosis of growth hormone deficiency (GHD) in children with short stature, whose height is below the third centile or -2 SD for the population norm, is based on the assessment of growth hormone $(\mathrm{GH})$ peaks in stimulation tests. $\mathrm{GH}$ secretion is regulated by multiple physiologic factors, including age, onset of puberty, nutritional status, and body weight [1]. $\mathrm{GH}$ secretion is pulsatile and serum concentrations are low during the daytime; hence, provocative tests of $\mathrm{GH}$ level are used to determine $\mathrm{GH}$ status, rather than a single basal GH estimation. Diagnosis of GHD in short children is based on GH provocative testing with a GH cut-off set in different centres at 7 or $10 \mu \mathrm{g} / \mathrm{l}$ [2-4]. However there is no controlled, evidence-based gold standard for these cut-offs, which should distinguish normal GH secretion from complete GH deficiency [5]. In normally growing children, by modern immunometric methods and standards, $10 \mathrm{ng} / \mathrm{ml}$ is just below the mean response obtained by most provocative tests, and the fifth percentile lies below $5 \mathrm{ng} / \mathrm{ml}$ for most tests $[6,7]$. Poor reproducibility and a high incidence of false subnormal responses to different pharmacological stimuli are further limitations of GH stimulation tests [2]. The difficulties in discriminating between IGHD and ISS were clarified by studies, which showed that $85 \%$ of IGHD patients with two stimulated peak $\mathrm{GH}$ values $<10 \mathrm{ng} / \mathrm{ml}$ had normal $\mathrm{GH}$ secretion when re-tested 1-6 months later 38. The Endocrine Society has adopted a $4.1 \mathrm{ng} / \mathrm{ml}$ peak $\mathrm{GH}[9,10]$, whereas the $\mathrm{GH}$ Research Society in association with other Medical Societies, including the European Society of Endocrinology [10, 11], suggest peak GH cut-off limits ranging from 4.2 to $11.5 \mathrm{ng} / \mathrm{ml}$ based on body mass index (BMI) [12]. In Poland the diagnosis is based on $\mathrm{GH}$ concentration below $10 \mathrm{ng} / \mathrm{ml}$ [13]. It is commonly accepted that children with severe $\mathrm{GH}$ deficiency with $\mathrm{GH}$ concentrations below $5 \mathrm{ng} / \mathrm{ml}$ should be treated with $\mathrm{rGH}$. However, indications for such a therapy remain disputable in children with so-called partial GH deficiency (pGHD), with $\mathrm{GH}$ concentrations between 5 and $10 \mathrm{ng} / \mathrm{ml}$.

The aim of our study was to assess the effects of rGH therapy in children with pGHD deficiency compared to untreated children with ISS.

\section{Material and methods}

The study group comprised 54 patients at the mean age of 13.5 (SD 2.36) years, who were diagnosed as pGHD between 1997 and 2000 in the Department of Paediatrics and Paediatric Endocrinology, Medical University of Silesia, and were treated with $\mathrm{rhGH}$. After termination of the therapy in 2002-2012 they were retested, and patients with $\mathrm{GH}$ secretion $>10 \mathrm{ng} / \mathrm{ml}$ were diagnosed as transient pGHD. The control group comprised 32 sex- and age-matched subjects with ISS, diagnosed between 2005 and 2007, who were untreated with rhGH. Inclusion criteria for the first group were as follows: short stature when starting the treatment of $\mathrm{rhGH}$, termination of therapy with $\mathrm{rGH}$, completed process of growth (growth velocity $<1 \mathrm{~cm} / 2$ years), pGHD by means of growth hormone secretion between 5 and $10 \mathrm{ng} / \mathrm{ml}$ before treatment, and $\mathrm{GH}$ secretion within normal range after treatment (>10 $\mathrm{ng} / \mathrm{ml})$. Inclusion criteria for the control group were as follows: short stature during diagnosis, completion of the process of growth, and $\mathrm{GH}$ secretion within normal range at diagnosis. Patients with chromosomal abnormalities, dysmorphic disorders, skeletal dysplasia, children small for gestational age or with intrauterine growth retardation, with chronic disorders (such as gastrointestinal diseases, renal failure), abnormalities in magnetic resonance imaging (MRI) of the pituitary gland, and other endocrinopathies were excluded from the analysis.

All patients underwent measurement of height and weight, pubertal development, and bone age (BA) assessments during diagnosis of short stature. In order to assess the pituitary function of $\mathrm{GH}$ secretion, the nocturnal profile of $\mathrm{GH}$ (to determine the concentration of $\mathrm{GH}$ during sleep in five samples taken at intervals of 30 minutes) and two stimulation tests (the first after intravenous administration of insulin in a dose of $0.1 \mathrm{U} / \mathrm{kg}$ and obtaining the state of hypoglycaemia, and the second after oral administration of clonidine in a dose of $0.15 \mathrm{mg} / \mathrm{m}^{2}$ ) were performed. In both groups the final height was measured after completion of growth. In order to measure the final height in the ISS group, after telephone contact and setting up an appointment, patients' growth was measured by one of the authors (B.K-A) using a SECA Harpenden type portable stadiometer. Measurement of growth was performed three times to the nearest $1 \mathrm{~mm}$ and on the basis of the obtained average final height.

Based on the information from the medical records in both groups, and the measurements of growth in the control group, growth deficit expressed by the number of standard deviations from the population mean at the time of diagnosis (HSDSO) and after reaching final height (HSDSfin), chronological age (CA), BA, percentage BA delay as compared to the CA (BA/CA * $100 \%$ ), and the deficit of patients' height in relation to the mid-parental height (HSDS0-mpSDS) were analysed.

For all children the predicted adult height $(\mathrm{PH})$ was calculated according to the Bayley-Pinneau method, estimating the final height that subjects would achieve without treatment with rhGH. Deviation of mean of parental height from the population, 
expressed as mpSDS, was calculated according to the following formula:

$$
\operatorname{mpSDS}=\frac{\mathrm{SD}_{\text {mother }}+\mathrm{SD}_{\text {father }}}{1.61245}
$$

In both groups of children familial short stature (FSS) was defined. The limit value (HSDSlim) for the diagnosis of FSS was determined according to the following formula [14]:

$$
\text { HSDSlim }=\frac{1 / 2\left(S_{\text {mother }}+S D_{\text {father }}\right)}{1.61}-1.73
$$

FSS was recognised when the child's HSDS was greater than HSDSlim. The target height (TH) was calculated according to mpSDS, and for children with FSS the following formula was implemented [15]:

THSDS $=\operatorname{mpSDS} * 0.72$

\section{Statistical analysis}

The obtained data were collected in a database created in an Excel spreadsheet using Microsoft Office v. 2007. For each analysed median value parameters of the statistical analysis necessary to determine the significance of differences in the conduct comparisons were calculated. For each of the analysed averages, required parameters of the statistical analysis were calculated, in order to determine the significance differences in the conducted comparisons. The level of statistical significance was set at the level of $p<0.05$.

The study was approved by the local Ethics Committee at the Medical University of Silesia in Katowice, Poland.

\section{Results}

The inclusion criteria for the pGHD group were met by 54 patients, including 34 boys and 20 girls, nine of whom were defined as FSS (six boys and three girls). In the ISS group the data of 32 patients, 23 boys and nine girls, were obtained, including 12 children with FSS (11 boys and one girl).
Characteristics of the groups at the diagnosis of short stature

The values of CA and BA of the two groups before treatment were not statistically significant, but bone age delay expressed as a percentage of BA/CA was statistically greater in the study group (Table I). Stages of puberty in both groups were comparable. Most children presented Tanner stage two; 48\% (26 patients) in the study group and 50\% (16 patients) in the control group. A comparable number of children were in prepubertal stage; $41 \%$ (22 patients) in the study group and $44 \%$ (14 patients) in the control group. There were no significant differences between two groups with respect to growth deficit or deviation from the mid-parental height. Mean midparental height was also comparable between groups, and it was within the normal range for the population (Table II). Moreover, there were no significant differences between the groups in the predicted and target adult height, and in both groups it remained within normal ranges for the population (Fig. 1, 2).

Characteristics of the groups after therapy completion

The average treatment duration in the study group was \pm 3.8 (SD 1.8) years. The mean final height expressed as HSDSfin was within normal population range for (Fig. 3) and was greater than HSDSO in both groups. The average height gain in both groups was statistically significant, at 1.3 SD $(p<0.001)$ for the study group and 1.02 SD $(p<0.001)$ for controls. The difference in height gain between groups was statically significant $(p=0.0284)$. The comparison of HSDSfin and height gain in particular groups of patients is presented in Table III. After the exclusion of children with FSS there were no statistical differences in height gain between the study and control groups, and the height gain was $1.41 \mathrm{SD} \pm 0.67$ for the study group and 1.22 SD \pm 0.77 for the control group. The final height expressed in HSDSfin differed from mpSDS by -0.11 SD for the study group and by -0.2 SD for the control group. The differences between groups were not statistically significant (Fig. 3 , Table III).

Final height reached by children in both groups was comparable to predicted and target height, and the differences between groups were not statistically significant (Table IV).

Table I. Characteristics of the groups at the time of diagnosis

\begin{tabular}{llllllllll}
\hline Parameter & CA & \multicolumn{3}{c}{ BA } & \multicolumn{3}{c}{ \%BR } \\
\hline Group & Median & Mean & SD & Median & Mean & SD & Median & Mean & SD \\
\hline Study & 13.50 & 13.10 & 2.36 & 11.00 & 10.73 & 2.21 & 82.13 & 81.66 & 8.46 \\
\hline Control & 13.67 & 13.21 & 1.38 & 11.75 & 11.49 & 1.64 & 88.75 & 86.94 & 8.23 \\
\hline$p$ & 0.5888 & & & 0.1503 & & & $\mathbf{0 . 0 0 6 4}$ &
\end{tabular}

CA - calendar age expressed in years; BA - bone age expressed in years; BR - delayed bone age expressed as a BA / CA * 100; SD - standard deviation 
Table II. The average values characterising each group at the time of diagnosis

\begin{tabular}{llllllllll}
\hline Parameter & HSDSO & \multicolumn{3}{c}{ mpSDS } & \multicolumn{5}{c}{ HSDS0-mpSDS } \\
\hline Group & Median & Mean & SD & Median & Mean & SD & Median & Mean & SD \\
\hline Study & -2.72 & -2.84 & 0.56 & -1.26 & -1.38 & 0.90 & -1.53 & -1.48 & 0.75 \\
\hline Control & -2.61 & -2.67 & 0.43 & -1.46 & -1.45 & 0.90 & -1.29 & -1.22 & 0.90 \\
\hline$p$ & $>0.05$ & & & $>0.05$ & & & $>0.05$ & & \\
\hline
\end{tabular}

HSDSO - height standard deviation score zero; mpSDS - midparental standard deviation score; SD - standard deviation

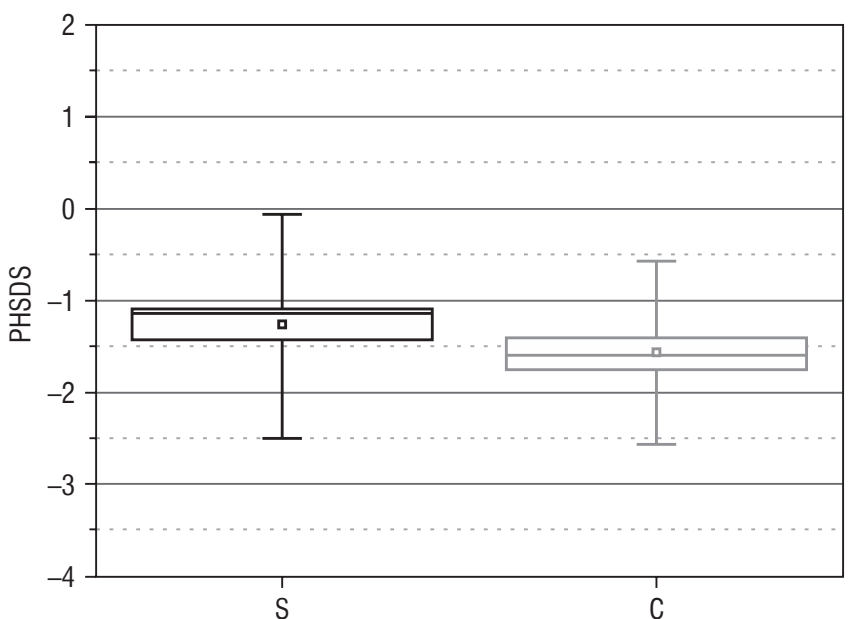

$工 \pm$ SD $\square \pm$ SE $\quad$ mean - median

Figure 1. PH SDS in both groups of patients ( $\mathrm{S}$ - study group, C - control group)

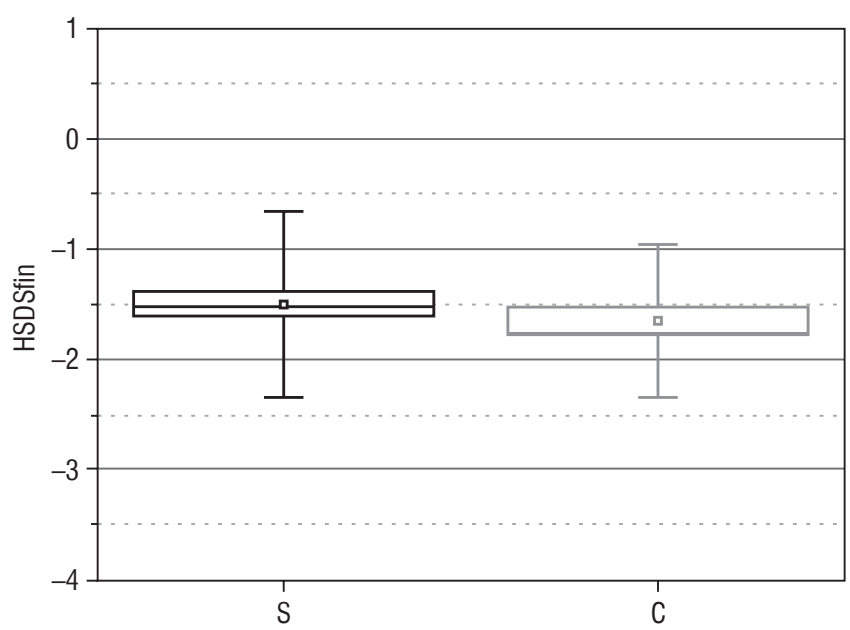

I \pm SD $\square \pm$ SE - mean - median

Figure 3. Final height in both groups ( $\mathrm{S}$ - study group, $\mathrm{C}-$ control group)

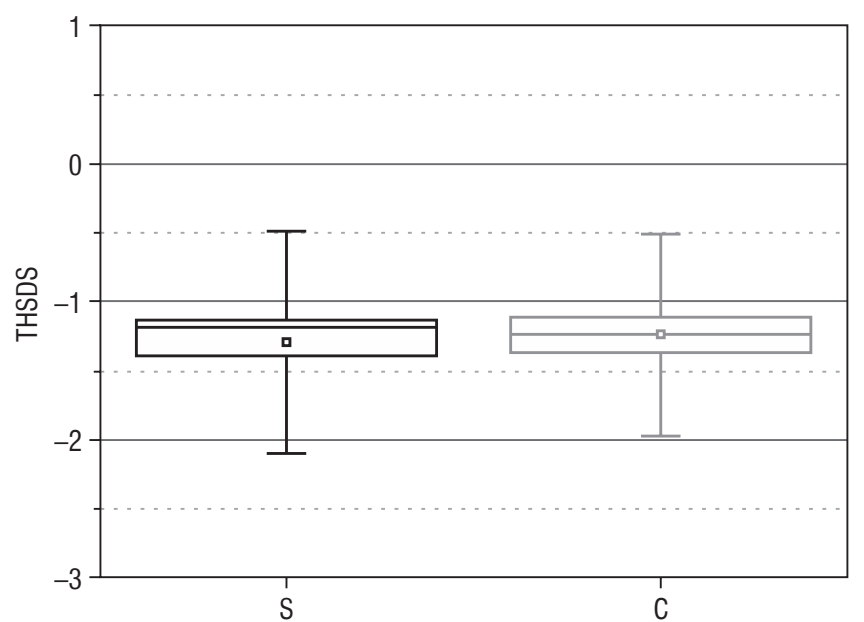

$工 \pm S D \quad \square \pm S E \quad$ a mean - median

Figure 2. TH SDS In both groups of patients ( $\mathrm{S}$ - study group, C - control group)

\section{Analysis of parameters affecting the final height}

In the study group 9\% of patients (five patients) and in the control group $6 \%$ of patients (two patients) presented very short $\mathrm{FH}$, expressed as HSDS $<-2.5$. Statistically significant negative correlation was found between the height gain and percentage of bone age delay in the study group, with a correlation coefficient of -0.37 . In the control group, the correlation coefficient was equal to -0.3 , but it did not show statistical significance (Fig. 4).

In the control group height gain was greater in children with more severe growth deficit during diagnosis of short stature (Fig. 5). For the other parameters (stage of puberty, deviation from parental height, duration of therapy), there were no statistically significant correlations for the study group. In both groups the final height correlated with mother's height, with correlation coefficient being $0.51(p=0.006)$ for the study group and 0.47 $(p=0.006)$ for the control group (Fig. 6). 
Table III. Parameters characterising the final height in both groups

\begin{tabular}{llllllllll}
\hline Parameter & HSDSfin & & \multicolumn{3}{l}{ HSDSfin - HSDSO } & \multicolumn{3}{c}{ hSDSfin - mpSDS } \\
\hline Group & Median & Mean & SD & Median & Mean & SD & Median & Mean & SD \\
\hline Study & -1.52 & -1.50 & 0.84 & 1.31 & $1.36^{1)}$ & 0.66 & -0.09 & -0.11 & 0.82 \\
\hline Control & -1.76 & -1.65 & 0.69 & 0.96 & $1.02^{2)}$ & 0.72 & 0.02 & -0.20 & 0.90 \\
\hline$p$ & $>0.05$ & & & $<0.05$ & & & & \\
\hline
\end{tabular}

1) and 2) $p<0.001$

HSDSfin - height standard deviation score final; HSDSO - height standard deviation score zero; mpSDS - midparental standard deviation score; SD - standard deviation

Table IV. $\mathrm{FH}$ in reference to $\mathrm{PH}$ and $\mathrm{TH}[\mathrm{cm}]$

\begin{tabular}{lllllll}
\hline Parameter & FH-PH & \multicolumn{5}{c}{ FH-TH } \\
\hline Group & Median & Mean & SD & Median & Mean & SD \\
\hline Study & -1.18697 & -1.90027 & 5.96253 & -1.36117 & -1.88685 & 4.81146 \\
\hline Control & 0.09865 & -0.57382 & 5.65882 & -2.08408 & -2.56124 & 4.83336 \\
\hline$p$ & $>0.05$ & & & $>0.05$ & & \\
\hline
\end{tabular}

FH - final height; $\mathrm{PH}$ - predicted height; $\mathrm{TH}$ - target height

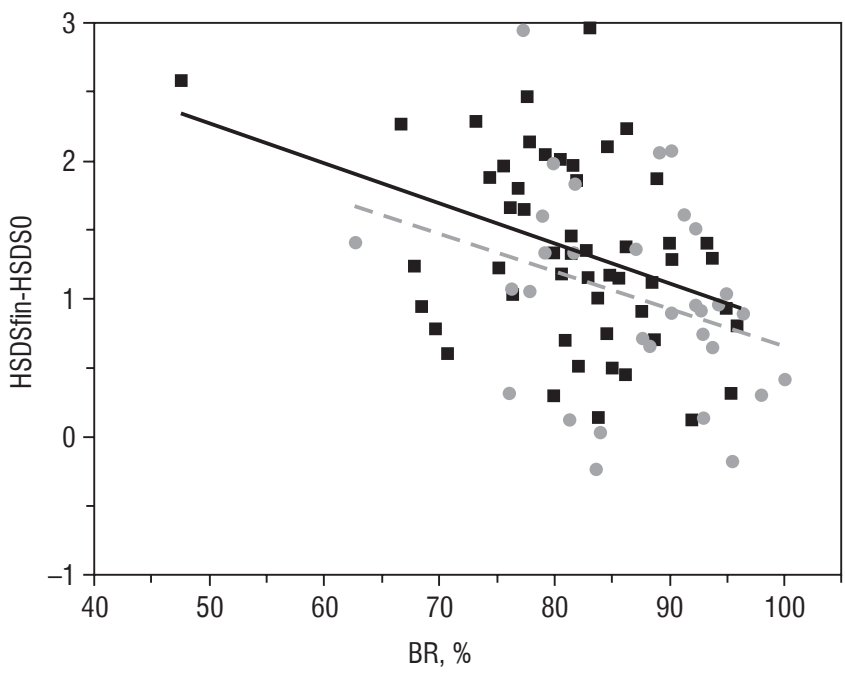

- HSDSfin-HSDSO S

$\mathrm{y}=3.731-0.029^{*} \mathrm{x}$ $r=-0.3721 ; p=0.00559$

- HSDSfin-HSDSO C

$--\mathrm{y}=3.3571-0.02692^{*} \mathrm{x}$

$r=-0.30568 ; p=0.08887$

Figure 4. Correlation between height gain and bone age delay ( $\mathrm{S}$ - study group, $\mathrm{C}$ - control group)

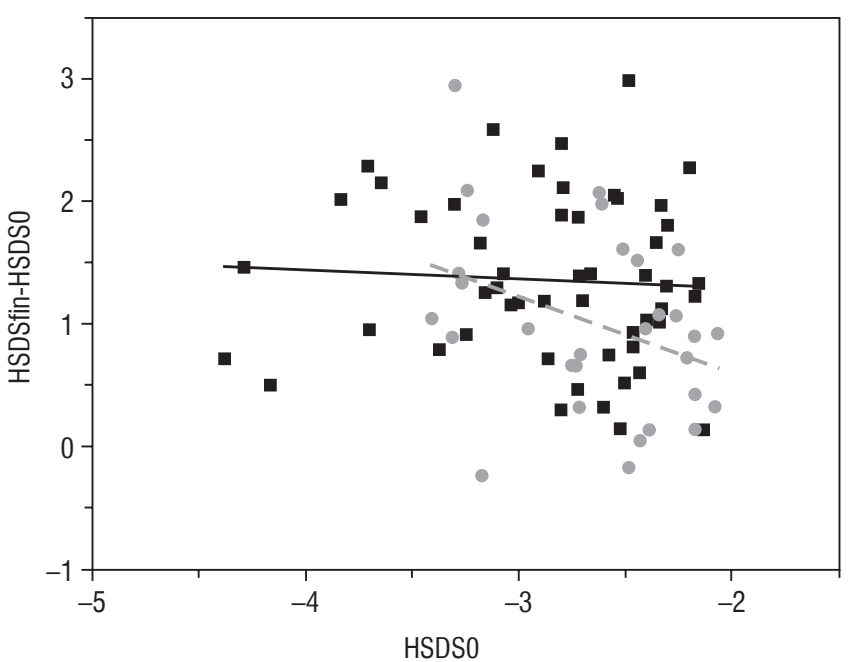

- HSDSfin-HSDSO S

- HSDSfin-HSDSO C

$--\mathrm{y}=-0.654-0.626^{*} \mathrm{x}$

$r=-0.368 ; p=0.0379$

Figure 5. Correlation between height gain and growth deficit during diagnosis of short stature ( $\mathrm{S}$ - study group, $\mathrm{C}$ - control group) 


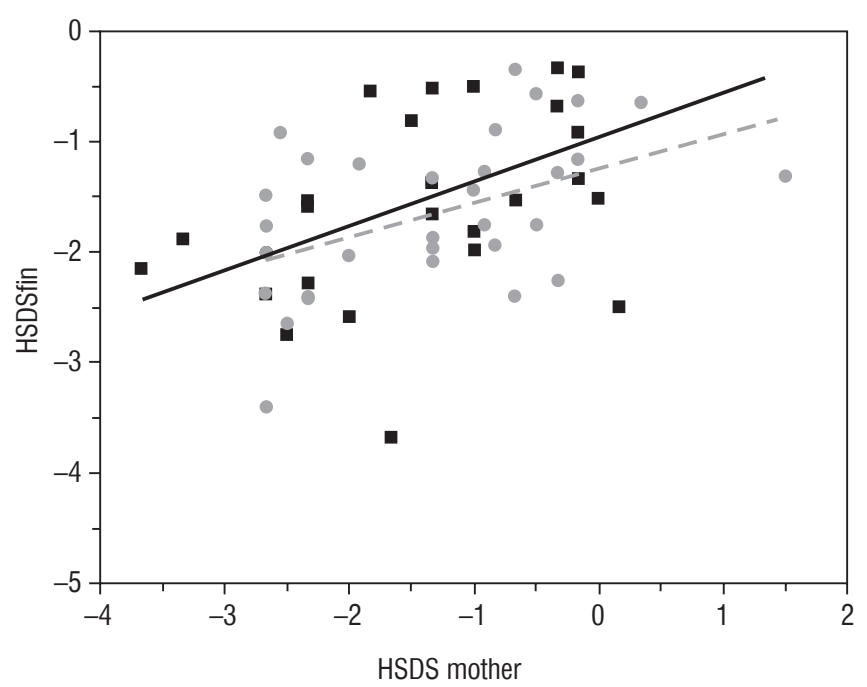

$$
\begin{array}{lr}
\text { - HSDSfinS } & \text { HSDSfinC } \\
-\mathrm{y}=-0955+0.4^{*} \mathrm{x} & -\mathrm{y}=-1.24+0.313^{*} \mathrm{x} \\
r=0.511 ; p=0.00654 & r=0.476 ; p=0.006
\end{array}
$$

Figure 6. Correlation between final height and mother's height (S - study group, C - control group)

\section{Discussion}

While there is no doubt that children with sGHD should be treated with $\mathrm{rhGH}$, the same therapy for patients with pGHD is often a subject of critical evaluation [16-20] because usually they have a poor response to treatment. In a number of publications the effects of treatment of children with pGHD compared with children with SGHD were analysed [21, 22]. Some studies comparing auxological parameters, including predicted final height, indicate more similarities in children with $\mathrm{PGHD}$ to children with ISS than to patients with sGHD [23]. Bang et al. [20], in a multicentre study, analysed response to treatment in the first year of therapy with rhGH in 400 patients. The authors concluded that children with pGHD were characterised by a similar response to treatment as a group with ISS. The greatest sensitivity was observed in the group with sGHD, in which the $\mathrm{GH}$ concentration was below $3 \mathrm{ng} / \mathrm{ml}$ before treatment. However, no significant differences in height gain between PGHD and ISS groups were observed. Due to a similar response to treatment in rhGH groups with PGHD and ISS it can be assumed that the cause of short stature in both groups was the same. Therefore, a strict distinction between pGHD and ISS cannot be determined because the continuum of responsiveness to rhGH varies across and within diagnostic groups [3]. Based on the literature, it can be assumed that the only value that distinguishes a group of children with pGHD from ISS patients is an arbitrarily accepted cut-off level for $\mathrm{GH}$ concentration of $10 \mathrm{ng} / \mathrm{ml}$. The cut-off level for $\mathrm{GH}$ is set arbitrarily and is not the same in different countries, in some being between 6 and $7 \mathrm{ng} / \mathrm{ml}$ [24-26]. Rosenfeld et al. [25] pointed to the fact that there is no strong evidence for any level of cut-off value in stimulating tests. Even though they are used in routine diagnosis, they have many limitations. Tests are carried out in non-physiological conditions, the definition of the correct answer is adopted arbitrarily, the effects are dependent on the age, characterised by low accuracy and low repeatability, and they are expensive and sometimes risky for the patient $[17,26]$. It is noteworthy that the poor reproducibility of the results of repeated $\mathrm{GH}$ stimulating tests with pharmacological agents has been well documented [27]. False subnormal responses to different pharmacological stimuli are further limitations of $\mathrm{GH}$ stimulation tests [3]. A study by Kriström et al. showed the difficulties in distinction between isolated GHD(IGHD) and ISS or SGA [8]. This study showed that $85 \%$ of IGHD patients with two stimulated peak $\mathrm{GH}$ values $<10 \mathrm{ng} / \mathrm{ml}$ and normal pituitary MRI had values of $\mathrm{GH}>10 \mathrm{ng} / \mathrm{ml}$ when re-tested 1-6 month later. The current guidelines for Growth Hormone Treatment recommend against reliance on $\mathrm{GH}$ provocative test results as the only diagnostic criterion of GHD [5, 26].

In the available literature we did not find studies comparing children with pGHD after treatment with untreated children with ISS therapy. Moreover, despite the widespread clinical studies, no clear answer regarding the real benefits of rhGH treatment in children with PGHD and ISS was shown. There were also no significant effects with respect to clinical aspects in improving the final height of children with ISS after rhGH therapy, and data from the literature suggest that children with pGHD have similar benefits from treatment with rhGH as children with ISS [28, 29].

In our study the only difference between the study and control group at the diagnosis of short stature was the value of $\mathrm{GH}$ secretion. Statistical analysis of height gain after reaching the final height showed a significant difference between children from the study group and from the control group $(p=0.028)$. However, it was not clinically significant because $0.3 \mathrm{SD}$ is an equivalent of $2 \mathrm{~cm}$ of the difference in final height. Of note, after the exclusion of children with FSS there were no statistically significant differences in height gain between the study and control groups. Moreover, in both groups the final height reached the population norms and the differences in the medium HSDSfin between groups were not statistically significant. In both groups the final height was similar to the predicted and target height. In all groups the final height was close to mpSDS, which proves that patients reached their genetic potential.

The results of our study indicate the low efficiency of rhGH therapy in children with pGHD. Study limitations may be the relatively short duration of treatment as well as the advanced age at the beginning of the therapy in comparison with other studies $[14,20]$. However, it is noteworthy that children from the control group reached final height in the normal range for the population and were not statistically different than patients from the study group. They also achieved their genetic potential even without treatment.

In our study, in both groups the final height was dependent on parents' height, especially the mother's height. Patients whose final height was below normal range for the population had the shortest mothers, and in the study and control groups the final height was dependent on their mothers. 


\section{Conclusions}

The results of our study do not show beneficial effects of rhGH treatment in children with pGHD as compared to untreated ISS subjects. Both groups also did not differ from each

\section{References}

1. Noorisaem R, Ka YO, Eun MY, et al. Growth Hormone Responses to Provocative Tests in Children with Short Stature. CMJ 2015; 51: 33-38. doi: 10.4068/cmj.2015.51.1.33

2. Growth Hormone Research Society. Consensus guidelines for the diagnosis and treatment of growth hormone $(\mathrm{GH})$ deficiency in childhood and adolescence: Summary statement of the $\mathrm{GH}$ Research Society. GH Research Society. J Clin Endocrinol Metab 2000; 85: 3990-3993. doi: 10.1210/jcem.85.11.6984

3. Savage MO, Bang P. The variability of responses to growth hormone therapy in children with short stature. Indian J Endocrinol Metab 2012; 16: 178-184. doi: 10.4103/2230-8210.104034

4. Bang P, Bjerknes R, Dahlgren J, et al. A comparison of different definitions of growth response in short prepubertal children treated with growth hormone. Horm Res Paediatr 2011; 75: 335-345. doi: $10.1159 / 000322878$

5. Gimberg A, DiVall SA, Polychronakos C, et al. Guidelines for Growth Hormone and Insulin-Like Growth Factor-I Treatment In Children and Adolescents: Growth Hormone Deficiency, Idiopathic Short Stature, and Primary Insulin-Like Growth Factor-I Deficiency. Horm Res Paediatr 2016; 86: 361-397. doi: 10.1159/000452150

6. Zadik Z, Chalew SA, Kowarski A. Assessment of growth hormone secretion in normal stature children using 24-hour integrated concentration of GH and pharmacological stimulation. J Clin Endocrinol Metab 1990; 71: 932-936. doi: 10.1210/jcem-71-4-932

7. Ghigo E, Bellone J, Aimaretti G, et al. Reliability of provocative tests to assess growth hormone secretory status. Study in 472 normally growing children. J Clin Endocrinol Metab 1996; 81: 3323-3327. doi: 10.1210/jcem.81.9.8784091

8. Kriström B, Aronson AS, Dahlgren J, et al. Growth hormone (GH) dosing during catch-up growth guided by individual responsiveness decreases growth response variability in prepubertal children with GH deficiency or idiopathic short stature. J Clin Endocrinol Metab 2009; 94: 483-490. doi: 10.1210/jc.2008-1503

9. Molitch ME, Clemmons DR, Malozowski S, et al. Evaluation and treatment of adult growth hormone deficiency: an Endocrine Society Clinical Practice Guideline. J Clin Endocrinol Metab 2006; 91:1621-1634. doi: 10.1210/jc.2005-2227

10. Cook DM, Yuen KC, Biller BM, et al. American Association of Clinical Endocrinologists medical guidelines for clinical practice for growth hormone use in growth hormone-deficient adults and transition patients - 2009 update: executive summary of recommendations. Endocr Pract 2009; 15: 1-29. doi: 10.4158/EP.15.6.580

11. Ho KK \& on behalf of the 2007 GH Deficiency Consensus Workshop Participants. GH Deficiency Consensus Workshop Participants. Consensus guidelines for the diagnosis and treatment of adults with GH deficiency II: a statement of the GH Research Society in other with respect to auxological data; therefore, it seems to be necessary to determine criteria other than arbitrarily taken $\mathrm{GH}$ concentration for starting rhGH treatment in children with pGHD.

association with the European Society for Pediatric Endocrinology, Lawson Wilkins Society, European Society of Endocrinology, Japan Endocrine Society and Endocrine Society of Australia. Eur J Endocrinol 2007; 157: 695-700. doi: 10.1530/EJE-07-0631.

12. Bogazzi F, Manetti L, Lombardi $M$ et al. Impact of different cut-off limits of peak $\mathrm{GH}$ after $\mathrm{GHRH}$-arginine stimulatory test, single IGF1 measurement, or their combination in identifying adult patients with GH deficiency. Eur J Endocrinol 2011; 164: 685-693. doi: 10.1530/ EJE-10-1068

13. Terapeutyczne programy lekowe. Leczenie niskorosłych dzieci z somatotropinową niedoczynnością przysadki (SNP). Załącznik Nr B19 obwieszczenie Ministra Zdrowia z dnia 19 sierpnia 2016 r. w sprawie wykazu refundowanych leków, środków spożywczych specjalnego przeznaczenia żywieniowego oraz wyrobów medycznych na dzień 1 września $2016 \mathrm{r}$.

14. Ranke MB, Lindberg A, KIGS International Board. Observed and predicted growth responses in prepubertal children with growth responses of growth hormone treatment by empirical variables. J Clin Endocrinol Metab 2010; 95: 1229-1237. doi: 10.1210/jc.2009-1471

15. Hermanussen M, Cole TJ. The Calculation of Target Height Reconsidered. Horm Res 2003; 59: 80-183. doi: 10.1159/000069321

16. Rappaport R. Growth Hormone Deficiency: Optimizing Therapy and New Issues. Indian J Pediatr 2012; 79: 224-228. doi: 10.1007/ s12098-011-0598-3

17. Richmond EJ, Rogol AD. Growth hormone deficiency in children. Pituitary 2008; 11: 115-120. doi: 10.1007/s11102-008-0105-7.

18. Hilczer M, Smyczyńska J, Stawerska R, et al. Evaluation of auxological parameters of the effi cacy of growth hormone $(\mathrm{GH})$ therapy in $\mathrm{GH}$-defi cient children, according to $\mathrm{GH}$ secretion before the therapy. Endokrynol Ped 2005; 4: 31-38.

19. Grimberg A, Allen DB. Growth hormone treatment for growth hormone deficiency and idiopathic short stature: new guidelines shaped by the presence and absence of evidence. Curr Opin Pediatr 2017; 29: 466-471. doi: 10.1097/MOP.0000000000000505

20. Bang P, Bjerknes R, Dahlgren J. A Comparison of Different Definitions of Growth Response in Short Prepubertal Children Treated with Growth Hormone. Horm Res Paediatr 2011; 75: 335-345. doi: $10.1159 / 000322878$

21. Mysłek-Prucnal M, Bieniasz J, Noczyńska A. Observation of children with total or partial somatotropic pituitary hypofunction treated with growth hormone (GH)]. Ped Endocrinol Diab Metab 2010; 16: 33-38.

22. Smyczyńska J, Lewiński A, Hilczer M, et al. Partial growth hormone deficiency (GHD) in children has more similarities to idiopathic short stature than to severe GHD. Endokrynol Pol 2007; 58: 182-187.

23. GH Research Society: Consensus guidelines for the diagnosis and treatment of growth hormone deficiency in childhood and adolescence: summary of the GH Research Society. J Clin Endocrinol Metab 2000; 85: 3990-3993. doi: 10.1210/jcem.85.11.6984 
24. Chaler EA, Ballerini G, Lazzati JM, et al. Cut-off values of serum growth hormone $(\mathrm{GH})$ in pharmacological stimulation tests (PhT) evaluated in short-statured children using a chemiluminescent immunometric assay (ICMA) calibrated with the International Recombinant Human GH Standard 98/574. Clin Chem Lab Med 2013; 51: 95-97. doi: 10.1515/cclm-2012-0505

25. Rosenfeld RG, Albertson-Wikland K, Cassorla F, et al. Diagnostic controversy: the diagnosis of Childhood growth hormone deficiency revisited. J Clin Endocrinol Metab 1995; 80: 1532-1540. doi: 10.1210/jcem.80.5.7538145

26. Collett-Solberg PF, Ambler G, Backeljauw PF, et al. Diagnosis, Genetics, and Therapy of Short Stature in Children: A Growth Hormone Research Society International Perspective. Horm Res Paediatr 2019; 12: 1-14. doi: 10.1159/000502231
27. Smyczyńska J, Stawerska R, Lewiński A, et al. Limited usefulness of the test of spontaneous growth hormone $(\mathrm{GH})$ nocturnal secretion as a screening procedure in diagnosing GH deficiency In children with short stature. Ann Agric Environ Med 2014; 4: 893-897. doi: 10.5604/12321966.1129954

28. Chaplin JE, Kriström B, Jonsson B, et al. When Do Short Children Realize They Are Short? Prepubertal Short Children's Perception of Height during 24 Months of Catch-Up Growth Hormone Treatment. Horm Res Paediatr 2012; 77: 241-249. doi: 10.1159/000337975

29. Cohen P, Germak J, Rogol AD, et al. Variable Degree of Growth Hormone (GH) and Insulin-Like Growth Factor (IGF) Sensitivity in Children with Idiopathic Short Stature Compared with GH-Deficient Patients: Evidence from an IGF-Based Dosing Study of Short Children. J Clin Endocrinol Metab 2010; 95: 2089-2098. doi: 10.1210/jc.2009-2139 